\author{
Marek ŚWISTAK \\ Jagiellonian University \\ marek.swistak@uj.edu.pl
}

\title{
GOOD GOVERNANCE AS A NEW FORM OF MANAGEMENT IN THE CONTEXT OF THE EUROPE 2020 STRATEGY
}

ABSTRACT The purpose of this article is to analyse the concept of good governance in the context of the implementation of the Europe 2020 Strategy. The analysis of the application of "good governance" in the implementation of the EU individual policies shows that it is an issue to which an important role from the point of view of grouping as a whole is assigned. As the crisis in the EU deepens, it becomes increasingly important. Meanwhile, the analysis of the state of "good governance" implementation in the aspect proposed by the EU indicates that the appropriate role was assigned to "good governance" at the level of strategic documents. The situation is different when it comes to the relation between "good governance" concept and its implementation in practice. It concerns not only the EU as a whole but also the individual countries such as Poland. Here, progress is mainly dependent on whether the implementation of a particular policy which is characterised by the relevant priorities and principles brings tangible benefits for national interests.

Keywords: Good Governance, Europe 2020 Strategy, Governance, European Union 
$\mathrm{T}$ he concept of "good governance" understood as effective management is significant, particularly in a time of economic crisis which affected not only the European Union as a whole, but also the individual countries. Although the impact of the crisis varies very widely in different countries, it is necessary to adapt the shape and the range of EU public policies ${ }^{1}$ to the challenges that come about as a result. Cases in point are the state of public finances, cutting funds for various EU policies (e.g. cohesion policy ${ }^{2}$ ), unemployment and increasing level of national egoism. By treating EU public policies and the activities of Member States that implement them as providing the citizens with specific political services, it is possible to propose the thesis that their quality is currently under severe threat.

National administrations are confronted with the challenge "better for less" i.e. meeting public expectations with the reduced budget while creating the business climate by providing even better services. ${ }^{3}$ That is why it is so important to undertake the analysis of the effectiveness of the EU public policies as well as of the principles which are a result of good management in the context of the Europe 2020 Strategy. However, it concerns not only the intended effect but also the way of implementation.

The subject of the "good governance" concept is of strategic importance, especially when it comes to the implementation of the EU public policies and their realisation. "Good governance" concentrates on the quality of governance understood as a method and the effects of governing. ${ }^{4}$ In this context, the pursuit of the EU public policies such as regional policy, common agricultural policy, environmental policy amounts to the efficiency of actions taken by the European Union and the national administrative structures. The quality of realisation of the public policies to a great extent has to do with an opportunity for social and economic development of the countries and their individual regions.

Due to the fact that the EU provides vast financial resources for the implementation of various policies, it treats "good governance" as a horizontal rule based largely on efficiency criteria ${ }^{5}$ of the actions taken by the administration. ${ }^{6}$ This does not mean that the "good governance" concept is treated as an either-or matter. This would mean that

Cf. A. Zybała, Polityki publiczne, Warszawa 2012, p. 23.

2 Cf. 'Council Regulation (EU, EURATOM) No. 1311/2013 of 2 December 2013 laying down the multiannual financial framework for the years 2014-2020', Official Journal of the European Union, L 347, 20 December 2013.

3 Cf. European Commission, Communication from the Commission 'Annual Growth Survey 2014', Brussels, 13 November 2013, $\operatorname{COM(2013)~} 800$ final, p. 13.

4 Cf. S. Kadelbach, 'European Administrative Law and the Law of a Europeanized Administration' in Ch. Joerges, R. Dehousse (eds.), Good Governance in Europe's Integrated Market, Oxford 2002, pp. 167-207 (Collected Courses of the Academy of European Law, 11/2).

5 Cf. Ministerstwo Rozwoju Regionalnego, Koncepcja good governance - refleksje do dyskusji, Warszawa 2008, p. 43.

6 Cf. European Commission, Promoting good governance. European Social Fund thematic paper, Luxembourg 2014, p. 4 . 
the given structures implement the concept in its entirety or they do not do that at all. In fact, the principles of good managing are implemented by various state structures to varying degrees. Thus, there is no identified critical mass, something like a "point of no return" in the implementation in a given policy, as well as no level of excellence that would be described as a case in which all of the principles are met. "Good governance" is a challenge and a call for continuous quality improvement. In this sense it is the natural process of improving efficiency which should take place during the process of the implementation of a certain policy.

\section{THE NOTION OF "GOOD GOVERNANCE" CONCEPT AND THE EUROPE 2020 STRATEGY}

The term "good governance" made its first formal appearance in the agenda-related documents of the World Bank in the early nineties. On the basis of experience in the running of assistance projects directed at developing countries which was gained by the institution, it was observed that despite implementing various assistance programs, which were possible to benefit from only after certain conditions were fulfilled, the results remained unsatisfactory. ${ }^{7}$ Low effectiveness of the World Bank development programmes resulted from the fact that it was impossible for the beneficiary countries to make optimum use of the external support due to their insufficient administrative capacity. This has led to discussion about the ways to improve the quality of governance as a substantial part of support as well as a condition for the development aid. ${ }^{8}$

Pursuing EU public policies is, to some extent, an analogy of aid programmes implemented by the World Bank. Both the aid programmes and EU policies are focused on implementing changes, ${ }^{9}$ mainly qualitative ones, in the relevant area. The implementation of the "good governance" concept contributes to building trust in the society for actions taken by public administration which seeks to optimise its activities. According to the World Bank, the quality of public administration directly affects the economic environment and, hence, has a decisive impact on the productivity, competitiveness and economic growth ${ }^{10}$ which is crucial at a time of economic crisis in Europe. Successful implementation of the "good governance" concept is crucial, also with regard to the country's capacity to create favourable conditions for the development of a civil society and entrepreneurship. ${ }^{11}$ Therefore, "good governance" can be assimilated

Cf. C. Santiso, 'Good Governance and Aid Effectiveness: The World Bank and Conditionality', The Georgetown Public Policy Review, Vol. 7, No. 1 (2001), pp. 3-18.

8 Cf. T. G. Grosse, 'Czy Polska potrzebuje dobrego rządzenia?', Analizy i Opinie, Vol. 85 (2008), p. 2; N. Drejerska, 'Good governance w polskiej polityce regionalnej', at < http://www.wne.sggw.pl/czasopisma/pdf/EIOGZ_2010_nr83_s45.pdf>, 1 June 2014.

9 Cf. S. Agere, Promoting Good Governance. Principles, Practices and Perspectives, London 2000, p. 1.

10 Cf. K. Schwab, The Global Competitiveness Report 2013-2014, World Economic Forum, Geneva 2013, pp. 3-5.

11 Cf. Ministerstwo Rozwoju Regionalnego, Koncepcja good governance..., p. 3. 
with institutionalized methods of coordination of activities which lead to the adoption and implementation of the decisions. ${ }^{12}$

The information above motivates the following question: What features the policy should have to conform to the "good governance" concept? Answering this question must be preceded by clarifying the concept of "governance" which is essential in light of "good governance". The term does not refer exclusively to activities of public authority perceived as the government in modern democracy. It also includes broader activities and processes of governing, relating to the different ways of coordinating social life. ${ }^{13} \mathrm{In}$ this respect the government can be perceived as one of the many institutions involved in the process of effective governance. ${ }^{14}$

The World Bank sees "governance" as a way of exercising authority by economic, political and social institutions. Of course, governance refers not only to institutions in a formal sense but also to the processes that occur in and between them. These processes, in turn, evolve into concrete decisions about governance. The UN pays special attention to the aforementioned processes, stating that "governance" primarily includes mechanisms and processes through which citizens and interest groups make their points clear, enforce their rights, but also carry out their duties. ${ }^{15}$

"Good governance" therefore relates to two fundamental aspects. The first one is connected with the functioning of the institution, that is the administration and public authorities in a material sense (irrespective of the level). The second one focuses on decision-making processes. As commonly understood, good governance refers to the involvement of the interest groups and other stakeholders (e.g. social and non-governmental organisations) in the decision-making process.

The Europe 2020 strategy plays a far from insignificant role when it comes to the implementation of the EU public policies. It constitutes a roadmap to which all UE development activities and in consequence, Member States, are subject. It includes the acceleration of the development of the whole grouping that is to be based on innovations. The Strategy aims to implement complementary activities in three dimensions: (1) knowledge-based economy; (2) support of the resource efficient (therefore more competitive) and environmentally friendly economy; (3) social inclusion understood as high level of employment, ensuring social and territorial cohesion. To be sustainable, the ambitious objectives of the Strategy that are achieved not only at the political level but also at the administrative level, have to be implemented by taking account of the

12 See T. A. Börzel, Y. Pamuk, A. Stahn, 'Good Governance in The European Union', Berlin Working Paper on European Integration, No. 7 (2008), p. 6.

13 Cf. J. Hausner, Zarzadzanie publiczne, Warszawa 2008, p. 402.

14 Cf. A. Heywood, Teoria polityki. Wprowadzenie, transl. by M. Jasiński, B. Maliszewska, D. Stasiak, Warszawa 2009, pp. 77-78.

15 The World Bank, 'Governance and Good Governance: Varying Definitions', at < http://web.worldbank.org/WBSITE/EXTERNAL/COUNTRIES/MENAEXT/EXTMNAREGTOPGOVER NANCE/0,,contentMDK:20513159 pagePK:34004173 piPK:34003707 theSitePK: 497024,00.html>, 1 June 2014. 
principles of the "good governance". Otherwise, the Europe 2020 Strategy might suffer the same fate as its predecessor - the Lisbon Strategy.

The failure of the Lisbon Strategy should constitute the starting point of the construction of the Europe 2020 Strategy implementation system. The question which logically arises is whether the Europe 2020 Strategy really is a new quality. In order to provide the answer to this question, two dimensions have to be taken into consideration: the substantive dimension and the management mechanisms. The experts say that in the case of the Lisbon Strategy both the construction and the implementation mechanisms were clearly of insufficient quality. On the one hand, the blame was put on imprecise development objectives, ${ }^{16}$ on the other hand, on the method of implementation based on not binding actions of Meber States under the open method of coordination. ${ }^{17}$

If we take a closer look at the records of the Europe 2020 Strategy, it would be helpful to direct our attention to the fact that the document represents a compromise between Member States and the EU institutions. The discussion during the preparation of the Strategy was held between the least developed countries whose primary objective was to catch up with the EU average and the developed countries which saw development opportunities only in innovations. In both cases the objective may be considered as one single aim but the methods of implementation are different, just like the resulting investment requirements. These differences make individual countries try to use the UE strategies to achieve their own development objectives i.e. to maximise the benefits for their national interests. Therefore, the Europe 2020 Strategy is a compromise between the old Member States and those whose length of membership in the UE does not exceed 10 years. In technical terms, the Europe 2020 Strategy does not set a new standard in comparison to the Lisbon Strategy since it refers to two objectives i.e. employment and economic growth which were also included in the Lisbon Strategy.

Many people believe that the actions formulated within the framework of the Lisbon Strategy reveal some inconsistencies. It is useful to draw attention to two such cases. The first example refers to fiscal consolidation efforts i.e. limitation of expenditure. However, these actions are accompanied by a package of poverty prevention and investment projects. The other inadequacy refers to continuing the efforts to improve the functioning of the common market and macroeconomic stabilization of the euro area. These measures are accompanied by numerous suggestions for the intervention operations. One example of this is the EU industrial policy. The emphasis is put less on protecting the free market mechanisms and more on protection of the free market itself. ${ }^{18}$

The Europe 2020 Strategy does very little to change the management structures within the Lisbon Strategy. This would not alter the fact that the European Commis-

16 Cf. P. Lenain, U. Bützow Mogensen, V. Royuela-Mora, Strategia Lizbońska na pótmetku. Oczekiwania a rzeczywistość, Warszawa 2005, p. 42 (Raporty CASE, 58).

17 Cf. T. G. Grosse, W objęciach europeizacji. Wybrane przyktady z Europy Środkowej i Wschodniej, Warszawa 2012, pp. 67-69.

18 Cf. idem, 'Doświadczenia Strategii Lizbońskiej - perspektywy Strategii “Europa 2020”: o kontynuacji i zmianach w polityce UE', Zarzadzanie Publiczne, Vol. 1 (2010), pp. 13-14. 
sion managed to push through some solutions aimed at the increased consolidation of the management of the development activities. It leads to greater supervision over Member States mainly in the context of economic governance which was caused by problems with consolidation of public finances in some of the Member States. ${ }^{19} \mathrm{New}$ elements include the thematic approach i.e. focusing on achieving indicators in areas regarded as particularly important from the point of view of the Strategy. Five indicators were established that are to be achieved at a European scale. ${ }^{20}$

The so-called flagship initiatives (which are seven within the Europe 2020 Strategy) serve the purpose of the Strategy. Other elements are national reports written in the context of the European Semester ${ }^{21}$ or the recommendations to Member States. Thus, the European Commission managed to strengthen its competences relating to the monitoring of the implementation of the Strategy. ${ }^{22}$ Pressure for consolidation of public finances in Member States is criticized by some analysts for too much focus on controlling the fiscal deficit and on the government debt instead of promoting economic growth. Additionally, it is noticeable that there is no political compromise when it comes to the implementation of the flagship initiatives among Member States. ${ }^{23}$

\section{WHAT DOES MODERN GOVERNANCE MEAN?}

Answering the question about the desired features of the modern governance is more effective when these features are compared with the characteristics of the traditional governance model. The implementation of public policies understood as governing according to the indicators of "good governance" requires from the government, the administration and the society to apply the following rules: openness, partnership, accountability, efficiency, effectiveness and consistency. In such systems of features in

19 Cf. European Commission, Communication from the Commission 'Europe 2020. A Strategy for smart, sustainable and inclusive growth', Brussels, 3 March 2010, COM(2010) 2020 final, p. 30.

20 The indicators concerned here are: (1) 75\% of the population aged 20-64 should be employed; (2) $3 \%$ of the Union's GDP should be invested in R\&D; (3) the objectives of “20/20/20" package related to EU climate and energy targets have to be met (including an increase to $30 \%$ of emissions reduction if the conditions are right); (4) the number of people leaving school early has to be reduced to $10 \%$ and at least $40 \%$ of the younger generation should have a tertiary degree; (5) 20 million fewer people should be at risk of poverty. Cf. European Commission, Communication from the Commission 'Europe 2020..., 3 March 2010, p. 10.

21 Mechanism for cyclical coordination of the economic policies of the Member States. The essential characteristic of coordination is taken into account in the European dimension in the planning of the national economic policies. See J. W. Tkaczyński, M. Świstak, Encyklopedia polityki regionalnej i funduszy europejskich, Warszawa 2013, pp. 473-476 (Unia Europejska).

22 Cf. T. G. Grosse, 'Doświadczenia Strategii Lizbońskiej...’, p. 18.

23 Cf. K. A. Armstrong, 'The Lisbon Agenda and Europe 2020: From the Governance of Coordination to the Coordination of Governance', Queen Mary School of Law Legal Studies Research Paper, No. 89/2011, p. 2, 28. 
governance, the method of the implementation and the effects are taken into account. In order to identify some specific features of "good governance", they need to be compared with the characteristics of the so-called traditional governance.

Table 1. The comparison of the characteristics of the traditional and the modern governance

\begin{tabular}{|c|c|}
\hline $\begin{array}{l}\text { Features of the traditional governance } \\
\text { (governing) }\end{array}$ & $\begin{array}{l}\text { Features of the modern (good) governance } \\
\text { ("good governance") }\end{array}$ \\
\hline $\begin{array}{l}\text { Lack of total transparency in the rules of ope- } \\
\text { rations of the public authority }\end{array}$ & $\begin{array}{l}\text { Taking decisions and the enforcement of the de- } \\
\text { cisions (governing) in an open and transparent } \\
\text { manner, in compliance with applicable law and } \\
\text { procedures (openness) }\end{array}$ \\
\hline $\begin{array}{l}\text { Limited (often negligible) scope of participa- } \\
\text { tion in achieving policy functions }\end{array}$ & $\begin{array}{l}\text { Application of different methods for encouraging } \\
\text { social participation in public sector activities, parti- } \\
\text { cularly in the government }\end{array}$ \\
\hline $\begin{array}{l}\text { Limited opportunities for calling the govern- } \\
\text { ment to account for the commitments taken }\end{array}$ & $\begin{array}{l}\text { Social monitoring of the actions of the government } \\
\text { (country) and creating the institutional conditions } \\
\text { for the enforcement of the commitments taken by } \\
\text { the government }\end{array}$ \\
\hline $\begin{array}{l}\text { Limited scope of application of the economic } \\
\text { balance when it comes to the decisions of the } \\
\text { government and the evaluation of their results }\end{array}$ & $\begin{array}{l}\text { Application of the economic balance when taking } \\
\text { decisions }\end{array}$ \\
\hline $\begin{array}{l}\text { Emphasis on the effectiveness in implement- } \\
\text { ing of the decisions of the government (public } \\
\text { authority) }\end{array}$ & $\begin{array}{l}\text { Creating the conditions (particularly the insti- } \\
\text { tutional ones) for the implementation of public } \\
\text { objectives to maximize in an effective way the } \\
\text { effect and the amount of work performed by the } \\
\text { government }\end{array}$ \\
\hline $\begin{array}{l}\text { Focusing on the achievement of one kind of } \\
\text { public policy (e.g. sectoral policy) }\end{array}$ & $\begin{array}{l}\text { Ability to coordinate various national, communi- } \\
\text { ty, sectoral, territorial policies (within a multi-level } \\
\text { governance system) }\end{array}$ \\
\hline
\end{tabular}

Source: Badanie dotyczace stworzenia systemu wskaźników dla oceny realizacji zasady good governance w Polsce, ECORYS Polska, Warszawa 2008, p. 13.

The aforementioned principles do not form a closed catalogue; if anything they represent the minimum set of determinants of the "good governance". They are not selected in a principled way but depend on the context in which the high quality of the pursuing policies is their common determinant. The example of a slightly different catalogue of the principles of "good governance" is the catalogue prepared by the United Nations. The UN distinguishes as many as nine principles, noting that "good governance" is primarily an instrument for the elimination of poverty and promoting the development. ${ }^{24}$

24 It is not a completely strange attitude. Such a point of view was presented by the World Bank, especially in the 1990s. Cf. The World Bank, Reforming Public Institutions and Strengthening Governance. A World Bank Strategy, Washington 2000, p. XI, 2, 7 (World Bank e-Library). 
Table 2. The features of "good governance" according to the UN

\begin{tabular}{|c|c|}
\hline Feature & Explanation \\
\hline participation & $\begin{array}{l}\text { All people have a voice in decision-making, either directly or through } \\
\text { the appropriate institutions }\end{array}$ \\
\hline rule of law & $\begin{array}{l}\text { Legal framework should be fair and it should strengthen the impar- } \\
\text { tiality and human rights. Public institutions should have the ability } \\
\text { to fight against those breaking the law }\end{array}$ \\
\hline transparency & The free flow and access to information for the stakeholders \\
\hline responsiveness & $\begin{array}{l}\text { Institutions serve the interests of everyone. Mechanisms for invo- } \\
\text { lving various groups of stakeholders in the decision-making process. }\end{array}$ \\
\hline consensus orientation & $\begin{array}{l}\text { Mediation between different parties in order to reach agreement on } \\
\text { key issues }\end{array}$ \\
\hline equality & $\begin{array}{l}\text { Equal treatment for various interest groups. Everyone has the oppor- } \\
\text { tunity to improve or maintain their well-being }\end{array}$ \\
\hline effectiveness and efficiency & Operations meet the needs while making the best use of resources \\
\hline accountability & $\begin{array}{l}\text { Accountability of policy makers to the citizens and stakeholders for } \\
\text { their operations }\end{array}$ \\
\hline strategic vision & $\begin{array}{l}\text { Leaders and the public have a long-term perspective on good gover- } \\
\text { nance and the development of the society. Strategic assessment of the } \\
\text { operations. }\end{array}$ \\
\hline
\end{tabular}

Source: UNED Forum, WHAT, GLOBE Southern Africa, Governance for Sustainable Development. WHAT Governance Programme 'A Joint Initiative of the World Humanity Action Trust (WHAT), UNED Forum and Global Legislators Organisations for a Balanced Environment (GLOBE) Southern Africa', Cape Town 2001, pp. 21-22.

The concept of "good governance" is one of the public administration governance models. Taking into account the specificity of "good governance", attention should be devoted to two different models: the bureaucracy model and the new public management model. The first one is characterized by the presence of hierarchical relations and making many entities subjects to the head office. The head office determines the extent of responsibilities and jurisdiction of all the entities, provides them with the necessary resources and closely monitors their functioning. However, the new public management is a market model which allows the functioning of independent and equivalent entities. In this model, different entities carry out their activities independently. Relations between the entities consist in competition but also in cooperation on certain issues. Their mutual relations are governed by a written contract. ${ }^{25}$

As the efficiency is one of the common elements for "good governance" and new public management, it is appropriate to concentrate on its factors. It is significant to make a qualitative change in the functioning of the administration, or, in broader terms, the principles of "good governance" should be introduced at central level when it

25 Cf. J. Czaputowicz, 'Zarządzanie w administracji publicznej w dobie globalizacji' in idem (ed.), Administracja publiczna. Wyzwania w dobie integracji europejskiej, Warszawa 2008, pp. 148-152. 
comes to the implementation of public policies. At the same time, it should be remembered that changing the internal rules of operation of the centres of power is grossly insufficient. In this context, the World Bank stresses the three mechanisms that support the effectiveness and the "good governance" of the public sector. These include the following ${ }^{26}$ :

a) rules (internal rules concerning the functioning of the system and legal restrictions, such as rules of public finance management, audit procedures, administration based on civil service, independent judiciary, independence of the central bank, watchdog organizations)

b) partnership (decentralization which strengthen the identity of local communities and enable the active citizenship, surveys to evaluate public service contracts, participation rules on legislative processes at local level)

c) competitive pressure (competitive system of providing social services, private participation in public infrastructure, alternative methods of dispute resolution (ADR), outright privatization of certain activities which is an important factor in changes in the perception of the role of public authorities)

\section{EUROPEAN UNION'S APPROACH TO "GOOD GOVERNANCE"}

The presented understanding of the "good governance" concept is very close to the EU due to the fact that this organization is pursuing a number of policies in $28 \mathrm{Member}$ States that aim at the improvement of the quality of life of citizens. The common point of all the principles of "good governance" in the EU is the fact that they represent the basis to democracy and the rule of law in Member States. ${ }^{27}$ They also apply to all levels of governance: global, European, national, regional and local.

In the European Union's approach "good governance" is a component of the democratic system in which dialogue, debate, political participation and finally, protection of individual rights provided by the independent legislation are the key elements. The role of democracy in this context is to create the conditions for the activities of citizens. Therefore, EU institutions have to respond to the expectations of civil society concerning the openness of governments or the participation in decision-making. Only in this way can the EU approach a little bit a solution to the real problems of citizens.

Democracy, in the whole sense of this word, should guarantee citizens the possibility to participate in public debates. This means that, to the greatest extent possible, citizens should have access to reliable information concerning EU policies. According to the European Commission, it is essential since it strengthen acceptance of the decisions taken. In a European context, deliberations of the working groups on the implementation of the principles of "good governance" put the spotlight on the answers to the fol-

26 Cf. The World Bank, Reforming Public Institutions..., pp. XIII-XIV.

27 Cf. A. Mungiu-Pippidi, Transformative Power of Europe, p. 2, at <http://dx.doi.org/10.2139/ssrn. 2393389>, 1 June 2014. 
lowing two questions. First, what kind of competences should the Union institutions be provided with in order to fulfil their responsibilities and to communicate them. Second, how to make communication a strategic tool for EU governance. ${ }^{28}$

This approach to "good governance" appears to be too superficial since it steers the discussion on the effectiveness of the management of the decision-making processes towards the effective communication. The current debate focused mainly on aspects relating to the communication of the operations of EU policies. This is confirmed by the recommendations from $2001^{29}$ which concentrate on - except from educational services - on the communication strategy (at different levels of the EU administration) and on their transfer to the Internet. ${ }^{30}$ The communicative role of "good governance" is complemented by the call to improve the quality of the EU legislation, as well as of civil participation in this process. ${ }^{31}$

Another issue that was raised during the debate on the European form of "good governance" concept was decentralization of the legislative processes. The discussion centred on the mechanisms through which Member States, regions and civil society institutions will be able to participate in the formulation and implementation of the EU legal regulations. There was a consensus on the application of decentralization in such sectors in which it is possible and would contribute to increasing the efficiency. The issue of decentralization of the EU individual policies implementation was left, on each occasion, to the assessment from the point of view of the effectiveness of activities. $^{32}$

The result of the debate ${ }^{33}$ on "good governance" was the publication of the White Paper "European Governance" by the European Commission in 2001. The EC suggested five main criteria for "good governance" which relate to the following ${ }^{34}$ :

28 Cf. White Paper on European Governance 'Broadening and enriching the public debate on European matters', Work area no. 1, pp. 7-8, at <http://ec.europa.eu/governance/areas/group1/report_en.pdf>, 1 June 2014.

Ibid.

30 Reference may be made to the postulate to increase the number of electronic publications at the expense of conventional, printed ones. Ibid., pp. 18-20.

31 Cf. European Commission, Communication from the Commission to the European Parliament, the Council, the European Economic and Social Committee and the Committee of the Regions 'Smart Regulation in the European Union', Brussels, 8 October 2010, COM(2010) 543 final, and European Commission, Communication from the Commission to the European Parliament, the Council, the European Economic and Social Committee and the Committee of the Regions 'EU Regulatory Fitness', Strasbourg, 12 December 2012, COM(2012) 746 final.

32 Cf. White Paper on European Governance Decentralisation 'Better involvement of national, regional and local actors', Report by Working Group 3b, at <http://ec.europa.eu/governance/areas/group7/report_ en.pdf>, 1 June 2014.

33 Cf. Perceptions of The European Union a qualitative study of the Public's, attitudes to and expectations of The European Union in the 15 member states and the 9 candidate countries summary of the results, June 2001, at <http://ec.europa.eu/public_opinion/archives/quali/ql_perceptions_summary_en.pdf>, 1 June 2014.

34 Cf. Commission of the European Communities, European Governance - A white paper, Brussels, 25 July 2001, $\operatorname{COM(2001)~} 428$ final, pp. 10-11. 
- openness,

- participation,

- accountability,

- effectiveness,

- coherence.

Ad 1. Openness is applicable to administrative institutions which should be maximally transparent for the public and the citizens. An important role is played by the Member States which are supposed to clearly communicate the decisions taken, including at European level. Openness may be interpreted as the implementation of the right to good administration. It concerns the right of everyone to be heard before the decisions on matters concerning the individual are taken, the right of access to the case file or the obligation of the administration to justify their decisions. ${ }^{35}$ In the latter case, an official cannot make a decision based on insufficient or unclear grounds. ${ }^{36}$

Ad 2. Participation is understood as wide public participation in administrative work, at all levels of public authority (multilevel-partnership) and at all the main stages of the implementation of public policies i.e. from the conception through its realisation to the assessment of the policy. ${ }^{37}$ The commission emphasises the participation of social and non-governmental organisations in the work of administration (the so-called civil dialogue) and the representatives of employers and trade unions (the so-called social dialogue). Participation can contribute to the increase in the level of confidence and therefore to greater acceptance of the implemented policies.

Ad 3. Accountability means precise definition of the scope of responsibilities of various institutions, in particular ensuring the division of powers between the legislative and the executive authority. At the European level, it is the clear definition of the prerogatives of the individual EU institutions, as well as their areas of responsibility. At the national level, it relates to the responsibility of Member States for the implementation of the EU policies at every level.

Ad 4. Effectiveness concerns the improvements in the administrative capacity ("state capacity") related to effective, efficient and punctual ${ }^{38}$ realization of public policies objectives. The public policies objectives should be clearly specified on the basis of the future effects of the planned activities (evaluation) or past experience. As regards the EU policies, the effectiveness also depends on decisions to be taken in accordance with the principles of proportionality and subsidiarity. The proportionality principle implies that the instruments of providing public services and public policies will be pro-

35 Cf. art. 41 act. 2, the 'Charter of Fundamental Rights of the European Union', Official Journal of the European Union, C 83, 30 March 2010; Europejski Rzecznik Praw Obywatelskich, Zasady stuzby cywilnej mające zastosowanie do stużby cywilnej UE, Strasburg 2012, p. 6.

36 Cf. Art. 18 Act. 2, The European Code of Good Administrative Behaviour, Luxembourg 2005.

37 Cf. Commission of the European Communities, Communication from the Commission 'Towards a reinforced culture of consultation and dialogue - General principles and minimum standards for consultation of interested parties by the Commission', Brussels, 11 December 2002, COM(2002) 704 final, pp. 3-22. 
portionate to the objectives pursued i.e. implemented in an optimal and cost-effective way. Taking decisions at the appropriate level is related to the subsidiarity principle. ${ }^{39}$ According to the principle, the actions taken by higher levels of administration are only ancillary to the activities carried out at lower levels of governance. The point is that the structures at higher levels of the organization scheme should not, without a clear and justified need, take over the tasks that can be better and more effectively done by the structures at lower levels. ${ }^{40}$

Ad 5. Coherence means integration of the governance of various public policies, both European and national, and also the integration between different levels of public authority in respect of "multilevel governance" ${ }^{41}$ From the EU perspective, coherence applies also to the integration of the horizontal (demographic changes, climate changes), sectoral and territorial actions. It requires political leadership and big responsibility on the part of all the institutions (Union-related and national ones) in order to ensure a consistent approach under the complex system.

The European Commission's approach to the "good governance" concept is proactive. ${ }^{42}$ Therefore it is possible to list some areas in which EU actions would allow for a better implementation of the principle. These include the following ${ }^{43}$ :

1) Better involvement and greater openness. Irrespective of the area in which the EU creates the policy, it has to be clearer and simpler, so that it would be comprehensible to the citizens (e.g. online consultation, regular dialogue with regional and local partners).

2) Better policy and its implementation mechanisms. It relates to verifying whether certain actions must be taken in each case at European level or they should be implemented at lower levels of governance. The EC concludes that it has to be decided whether in each case it is necessary to refer to legislative measures as a method of conducting policy ("hard law"). In this context it is considered to use soft forms of implementation of the EU policies, such a new methods of governance (e.g. guidelines, recommendations, opinions, reports).

3) Contribution to the global concept of governance. It includes promoting "good governance" principles in third countries, also through the international non-governmental organizations (e.g. the World Bank).

4) Reorganization of the national and the EU institutions towards an increased

39 Cf. J. W. Tkaczyński, Ustrój federalny Niemiec a system decyzyjny Unii Europejskiej, Kraków 2005, pp. 113-132; idem, Varia europejskie, Toruń 2003, pp. 46-62; M. Bankowicz, J. W. Tkaczyński, Oblicza wspótczesnego państwa, Toruń 2002, pp. 167-182.

40 Cf. D. Kabat-Rudnicka, Zasada federalna a integracja ponadnarodowa. Unia Europejska między federalizmem dualistycznym a kooperatywnym, Kraków 2010, pp. 172-176.

41 Cf. Commission of the European Communities, Communication from the Commission 'The operating framework for the European Regulatory Agencies', Brussels, 11 December 2002, COM(2002) 718 final, pp. 2-14.

42 Cf. A System for Good Governance in The European Union, Contributions to the White Paper on Governance, p. 3, at <http://ec.europa.eu/governance/contrib_euromed_en.pdf>, 1 June 2014.

43 Cf. Commission of the European Communities, European Governance - A white paper, pp. 4-6. 
coordination of activities. It is necessary that Member States and the EU institutions cooperate among themselves for the purpose of developing a common coherent concept of "good governance" regarding longer-term objectives.

The implementation of one of the EU public policies, i.e. regional policy takes account of the good governance principles at each stage of the process. ${ }^{44}$ It is worth noting that the way to improve efficiency of the implementation of "good governance" concept is attributed to the application of the concept itself. In the case of regional policy it applies to a partnership-based approach of Member States to fund management at all levels (i.e. national, regional, local). Partnership refers to cooperation in the implementation of operational programmes, Partnership Contracts with municipal authorities, socio-economic partners, civil society representatives including those who take actions to preserve the natural environment and social inclusion..$^{45}$ The principles of "good governance" will determine in particular the efficient implementation of the territorial dimension of the cohesion policy (e.g. intelligent specialisations $\left.{ }^{46}\right) .{ }^{47}$

The implementation of EU policies in a medium term perspective requires policy and programming decisions to be taken. As has already been mentioned above, the Europe 200 Strategy defines the ambitious objective of modernizing the EU through the economic growth that can be characterized as: intelligent, sustainable and inclusive. The first objective which is related to the innovative economy and the third one that refers to public policy are not the primary sector of interest from the point of view of "good governance" concept implementation. The key objective is the second one which can be described as supporting the economy that is more competitive and more resource-efficient in a more environmentally friendly manner. ${ }^{48}$

Sustainable development extends beyond the area related to environmental protection. It also refers to the economic and social dimension. This is reflected in the arrangement of the objectives within the Europe 2020 Strategy, i.e. objective 1 and objective 3 . Sustainable development therefore means the development in which the

44 Cf. Communication from the Commission to the European Parliament, the Council, the European Economic and Social Committee and the Committee of the Regions 'Regional Policy Contributing to Sustainable Growth in Europe 2020', Brussels, 26 January 2011, COM(2011) 17 final, p. 5, 8, 21.

45 See Art. 5 Act 1, 'Regulation (EU) No. 1303/2013 of the European Parliament and of the Council of 17 December 2013 laying down common provisions on the European Regional Development Fund, the European Social Fund, the Cohesion Fund, the European Agricultural Fund for Rural Development and the European Maritime and Fisheries Fund and laying down general provisions on the European Regional Development Fund, the European Social Fund, the Cohesion Fund and the European Maritime and Fisheries Fund and repealing Council Regulation (EC) No 1083/2006,' Official Journal of the European Union, L 347, 20 December 2013.

46 Cf.: European Union, Regional Policy for Smart Growth in Europe 2020, Brussels 2011, pp. 6-8; T. G. Grosse, 'Inteligentna specjalizacja w Polsce. Czy potrafimy wykorzystać szansę?,', Samorząd Terytorialny, Vol. 10 (2013), pp. 5-13.

47 Cf. note 16, p. 29, 'Council Decision 2006/702/WE of 6 October 2006 on Community strategic guidelines oncohesion', Official Journal of the European Union, L 291, 21 October 2006.

48 Cf. European Commission, Communication from the Commission 'Europe 2020. A Strategy for smart, sustainable and inclusive growth', Brussels, 2 March 2010, COM(2010) 2020 final, p. 12, 16. 
integration of activities aimed at the economic growth as well as social activities take place, while maintaining ecological balance and durability of basic natural processes in order to guarantee the possibility of satisfying needs of various communities and citizens of both the existing and the future generations. ${ }^{49}$ However, the implementation ${ }^{50}$ of the above-listed objectives and development directions will require the use of the more effective tools than in the Lisbon Strategy. ${ }^{51}$ Hence, the key points from literature concerning this subject include: new methods of financial management, ${ }^{52}$ opportunities for expansion created by a large internal market, trade, economic policy and consistent rules of the Economic and Monetary Union..$^{53}$

The EU activities concerning "good governance" focus on increasing efficiency, transparency of actions taken by administration and justice system in order not only to improve the efficiency of the country but also to create a good economic climate. In this sense, "good governance" is a priority for the EU since it is essential in attempts to achieve the objectives of the Europe 2020 Strategy. Realization of this dimension of "good governance" entails taking specific actions which include: implementation of services based on e-administration, simplifying the business environment for running a business, reduction of bureaucracy by introducing easier procedures and regulatory systems. ${ }^{54}$

In the context of the Europe 2020 Strategy the implementation of actions related to "good governance" has a very practical dimension. It makes reference to the recommendations in the framework of the European Semester which are addressed to the Member States in order to improve the quality of the functioning of administration. The recommendations relate to making the public sector more efficient by improving cooperation between the various layers of government administration, introducing e-administration and reduction of bureaucracy. ${ }^{55}$

Funding for 2014-2020 is an example of practical actions taken in the context of the regional policy. In this period of programming the institutional capacity is not only

49 Cf. J. W. Tkaczyński, M. Świstak, Encyklopedia polityki regionalnej..., p. 593.

50 Cf. European Commission, Annex: Progress Report on The Europe 2020 Strategy to the Communication from the Commission to the European Parliament, the Council, the European Economic and Social Committee and the Committee of Regions 'Annual Growth Survey 2012', Brussels, 23 November 2011, $\operatorname{COM}(2011) 815$ final.

51 Cf. M. Duszczyk, 'Od Strategii Lizbońskiej do Europa 2020 - lekcja dla Unii Europejskiej' in J. Adamowski, K. A. Wojtaszczyk (eds.), Strategie rozwoju Unii Europejskiej, Warszawa 2010, pp. 513-531 (Wizje Europy, 10); T. G. Grosse, 'Doświadczenia Strategii Lizbońskiej..., pp. 5-19.

52 Cf. R. Thillaye, Gearing EU Governance towards Future Growth. The Side-Lining of Europe 2020 and its Worrying Consequences, London 2013, pp. 12-20.

53 Cf. E. Frejtag-Mika, 'Miejsce Europy w globalnym świecie entropii - stabilizacja czy rozwój' in S. Bukowski (ed.), Polityka kohezji i konwergencja gospodarcza regionów Polski oraz krajów Unii Europejskiej. Wybrane zagadnienia, Warszawa 2011, pp. 173-183.

54 Cf. European Commission, Communication from the Commission 'Annual Growth Survey 2014', pp. 13-15.

55 Cf. European Commission, Press release 'European Semester 2014: strengthening the recovery', Brussels, 13 November 2013, at <http://europa.eu/rapid/press-release_IP-13-1064_en.htm>, 1 June 2014. 
a technical issue related to training officials, but above all it is the way of delivering public services to the individuals and entrepreneurs. Perceiving "good governance" as a method of building trust and confidence has to direct the researcher's attention to the human capital formation. The high level of human capital in a particular Member State indicates higher ability to achieve development. At the same time, it should be remembered that "good governance" is contextual and that the following things are recognized as key factors: institutional stability, involvement of the interested parties, adaptation of the objectives and effectiveness, cooperation between the entities involved. ${ }^{56}$

\section{SUMMARY}

The analysis of the application of "good governance" in the implementation of the EU individual policies shows that it is an issue to which an important role is attached from the point of view of grouping as a whole. As the crisis in the EU deepens, it becomes increasingly important. Meanwhile, the analysis of the state of "good governance" implementation in the aspect proposed by the EU indicates that an appropriate role was assigned to "good governance" at the level of strategic documents.

The situation is different when it comes to the relation between the "good governance" concept and its implementation in practice. It concerns not only the EU as a whole but also the individual countries such as Poland. Here, progress is mainly dependent on whether the implementation of a particular policy which is characterised by the relevant priorities and principles brings tangible benefits to national interests. Where there is the minimum range of benefits or they do not exceed the costs of implementing "good governance" principles, the process remains very slow. To this must be added the reluctance of administrative structures to adopt and implement modernization stimuli since they frequently affect the system of previous interests. Although Poland presents a well-developed government structure of diagnostic and programming documents, the situation is unsatisfactory when it comes to the implementation of "good governance" in the practical activities of Polish administration. The quality of its functioning still deviates significantly from the EU standards.

The analysis of the substantive dimension and governance system in the Europe 2020 Strategy clearly indicates that it does not constitute a breakthrough in the management of the policies which arise from it. A lack of breakthrough is also related to "good governance" mechanisms which, although not excluded from the implementation system of the Strategy, were not recognised as crucial. The implementation of the new financial perspective 2014-2020 will probably solve the problem. Another touchstone for the effectiveness of "good governance" may be the effects achieved or the lack thereof.

56 Cf. J. de Koning et al., Evaluation of the ESF Support to Capacity Building. Final Report, Rotterdam 2006, pp. 116-123. 


\section{BIBLIOGRAPHY}

Agere S., Promoting Good Governance. Principles, Practices and Perspectives, London 2000.

Armstrong K. A., 'The Lisbon Agenda and Europe 2020: From the Governance of Coordination to the Coordination of Governance', Queen Mary School of Law Legal Studies Research Paper, No. 89/2011.

Badanie dotyczące stworzenia systemu wskaźników dla oceny realizacji zasady good governance $w$ Polsce, ECORYS Polska, Warszawa 2008.

Bankowicz M., Tkaczyński W. J., Oblicza wspótczesnego państwa, Toruń 2002.

Börzel T. A., Pamuk Y., Stahn A., 'Good Governance in the European Union', Berlin Working Paper on European Integration, No. 7 (2008).

'Charter of Fundamental Rights of the European Union', Official Journal of the European Union, C 83, 30 March 2010.

Commission of the European Communities, Communication from the Commission 'The operating framework for the European Regulatory Agencies', Brussels, 11 December 2002, COM(2002) 718 final.

Commission of the European Communities, Communication from the Commission 'Towards a reinforced culture of consultation and dialogue - General principles and minimum standards for consultation of interested parties by the Commission', Brussels, 11 December 2002, COM(2002) 704 final.

Commission of the European Communities, European Governance - A white paper, Brussels, 25 July 2001, COM(2001) 428 final.

'Council Decision 2006/702/WE of 6 October 2006 on Community strategic guidelines on cohesion', Official Journal of the European Union, L 291, 21 October 2006.

'Council Regulation (EU, Euratom) No 1311/2013 of 2 December 2013 laying down the multiannual financial framework for the years 2014-2020', Official Journal of the European Union, L 347, 20 December 2013.

Czaputowicz J., 'Zarządzanie w administracji publicznej w dobie globalizacji' in idem (ed.), Administracja publiczna. Wyzwania w dobie integracji europejskiej, Warszawa 2008.

Drejerska N., 'Good governance w polskiej polityce regionalnej', at <http://www.wne.sggw.pl/ czasopisma/pdf/EIOGZ_2010_nr83_s45.pdf>.

Duszczyk M., 'Od Strategii Lizbońskiej do Europa 2020 - lekcja dla Unii Europejskiej' in J. Adamowski, K. A. Wojtaszczyk (eds.), Strategie rozwoju Unii Europejskiej, Warszawa 2010 (Wizje Europy, 10).

The European Code of Good Administrative Behaviour, Luxembourg 2005.

European Commission, Annex: Progress Report on The Europe 2020 Strategy to the Communication from the Commission to the European Parliament, the Council, the European Economic and Social Committee and the Committee of Regions 'Annual Growth Survey 2012', Brussels, 23 November 2011, COM(2011) 815 final.

European Commission, Communication from the Commission 'Annual Growth Survey 2014, Brussels, 13 November 2013, COM(2013) 800 final. 
European Commission, Communication from the Commission 'Europe 2020. A strategy for smart, sustainable and inclusive growth', Brussels, 2 March 2010, $\operatorname{COM(2010)~} 2020$ final.

European Commission, Communication from the Commission 'Europe 2020. A Strategy for smart, sustainable and inclusive growth', Brussels, 3 March 2010, COM(2010) 2020 final.

European Commission, Communication from the Commission to the European Parliament, the Council, the European Economic and Social Committee and the Committee of the Regions 'Smart Regulation in the European Union', Brussels, 8 October 2010, COM(2010) 543 final.

European Commission, Communication from the Commission to the European Parliament, the Council, the European Economic and Social Committee and the Committee of the Regions 'EU Regulatory Fitness', Strasbourg, 12 December 2012, COM(2012) 746 final.

European Commission, Communication from the Commission to the European Parliament, the Council, the European Economic and Social Committee and the Committee of the Regions 'Regional Policy contributing to sustainable growth in Europe 2020', Brussels, 26 January 2011, $\operatorname{COM}(2011) 17$ final.

European Commission, Press release 'European Semester 2014: strengthening the recovery', Brussels, 13 November 2013, at <http://europa.eu/rapid/press-release_IP-13-1064_en.htm>.

European Commission, Promoting good governance. European Social Fund thematic paper, Luxembourg 2014.

European Union, Regional Policy for Smart Growth in Europe 2020, Brussels 2011.

Europejski Rzecznik Praw Obywatelskich, Zasady stużby cywilnej majacce zastosowanie do stużby cywilnej UE, Strasburg 2012.

Frejtag-Mika E., 'Miejsce Europy w globalnym świecie entropii - stabilizacja czy rozwój' in S. Bukowski (ed.), Polityka kohezji i konwergencja gospodarcza regionów Polski oraz krajów Unii Europejskiej. Wybrane zagadnienia, Warszawa 2011.

Grosse T. G., 'Czy Polska potrzebuje dobrego rządzenia?', Analizy i Opinie, Vol. 85 (2008).

Grosse T. G., 'Doświadczenia Strategii Lizbońskiej - perspektywy Strategii “Europa 2020”: o kontynuacji i zmianach w polityce UE’, Zarządzanie Publiczne, Vol. 1 (2010).

Grosse T. G., 'Inteligentna specjalizacja w Polsce. Czy potrafimy wykorzystać szansę?', Samorząd Terytorialny, Vol. 10 (2013).

Grosse T. G., W objęciach europeizacji. Wybrane przyktady z Europy Środkowej i Wschodniej, Warszawa 2012.

Hausner J., Zarządzanie publiczne, Warszawa 2008.

Heywood A., Teoria polityki. Wprowadzenie, transl. by M. Jasiński, B. Maliszewska, D. Stasiak, Warszawa 2009.

Kabat-Rudnicka D., Zasada federalna a integracja ponadnarodowa. Unia Europejska między federalizmem dualistycznym a kooperatywnym, Kraków 2010.

Kadelbach S., 'European Administrative Law and the Law of a Europeanized Administration' in Ch. Joerges, R. Dehousse (eds.), Good Governance in Europe's Integrated Market, Oxford 2002 (Collected Courses of the Academy of European Law, 11/2).

Koning J. de et al., Evaluation of the ESF Support to Capacity Building. Final Report, Rotterdam 2006. 
Lenain P., Bützow Mogensen U., Royuela-Mora V., Strategia Lizbońska na pótmetku. Oczekiwania a rzeczywistość, Warszawa 2005 (Raporty CASE, 58).

Ministerstwo Rozwoju Regionalnego, Koncepcja good governance - refleksje do dyskusji, Warszawa 2008.

Mungiu-Pippidi A., Transformative Power of Europe, at <http://dx.doi.org/10.2139/ssrn. 2393389>.

'Regulation (EU) No. 1303/2013 of the European Parliament and of the Council of 17 December 2013 laying down common provisions on the European Regional Development Fund, the European Social Fund, the Cohesion Fund, the European Agricultural Fund for Rural Development and the European Maritime and Fisheries Fund and laying down general provisions on the European Regional Development Fund, the European Social Fund, the Cohesion Fund and the European Maritime and Fisheries Fund and repealing Council Regulation (EC) No 1083/2006', Official Journal of the European Union, L 347, 20 December 2013.

Santiso C., 'Good Governance and Aid Effectiveness: The World Bank and Conditionality', The Georgetown Public Policy Review, Vol. 7, No. 1 (2001).

Schwab K., The Global Competitiveness Report 2013-2014, World Economic Forum, Geneva 2013.

A System for Good Governance in The European Union, Contributions to the White Paper on Governance, at <http://ec.europa.eu/governance/contrib_euromed_en.pdf >.

Thillaye R., Gearing EU Governance towards Future Growth. The Side-Lining of Europe 2020 and its Worrying Consequences, London 2013.

Tkaczyński W. J., Ustrój federalny Niemiec a system decyzyjny Unii Europejskiej, Kraków 2005.

Tkaczyński W. J., Varia europejskie, Toruń 2003.

Tkaczyński W. J., Świstak M., Encyklopedia polityki regionalnej i funduszy europejskich, Warszawa 2013 (Unia Europejska).

UNED Forum, WHAT, GLOBE Southern Africa, Governance for Sustainable Development. WHAT Governance Programme A Joint Initiative of the World Humanity Action Trust (WHAT), UNED Forum and Global Legislators Organisations for a Balanced Environment (GLOBE) Southern Africa', Cape Town 2001.

White Paper on European Governance 'Decentralisation Better involvement of national, regional and local actors', Report by Working Group 3b, at <http://ec.europa.eu/governance/areas/ group7/report_en.pdf>.

White Paper on European Governance 'Broadening and enriching the public debate on European matters', Work area no. 1, at <http://ec.europa.eu/governance/areas/group1/report_ en.pdf>.

The World Bank, 'Governance and Good Governance: Varying Definitions', at <http://web. worldbank.org/WBSITE/EXTERNAL/COUNTRIES/MENAEXT/EXTMNAREGT OPGOVERNANCE/0,,contentMDK:20513159 pagePK:34004173 piPK:34003707 $\sim$ theSitePK:497024,00.html>.

The World Bank, Reforming Public Institutions and Strengthening Governance. A World Bank Strategy, Washington 2000 (World Bank e-Library). 
Zybała A., Politykipubliczne. Doświadczenia w tworzeniu i wykonywaniu programów publicznych $w$ Polsce i w innych krajach. Jak dziata państwo, gdy zamierza, chce, musi rozwiąać zbiorowe problemy swoich obywateli?, Warszawa 2012.

Marek ŚWISTAK Ph.D. - a lecturer in the Department of the Political System of the $\mathrm{EU}$ at the Institute of European Studies of the Jagiellonian University. His interests include the public policies of the EU, including the regional policy, the Common Agricultural Policy, the policy of the protection of the environment, the policy of the job market and the EU funds. He is the author or co-author of six monographs and joint publications in this field. Recently he published inter alia: Projekty europejskie. Praktyczne aspekty pozyskiwania i rozliczania dotacji unijnych (2011) [European projects. Practical aspects of the acquisition and balancing EU grants], Fundusze Unii Europejskiej a pozaekonomiczne czynniki wzrostu gospodarczego (2012) [EU funds and extra-economic factors of economic growth], Encyklopedia polityki regionalnej i funduszy europejskich (2013) [The encyclopedia of regional policy and EU funds], Wybrane polityki publiczne Unii Europejskiej. Stan i perspektywy (2015) [Selected public policies of the European Union. Current status and perspectives]. 